\title{
A short review on COVID-19: A great concern to public health
}

\author{
Ashok Chakraborty ${ }^{1 *}$, Anil Diwan ${ }^{2}$, Vijetha Chinige ${ }^{1}$, Preetam Holkar $^{1}$ and Vinod Arora ${ }^{1}$ \\ ${ }^{1}$ Allexcel, Inc. CT, USA \\ ${ }^{2}$ Nanoviricides, CT, USA
}

\begin{abstract}
Objectives: Very recently a novel coronavirus, SARS-CoV-2, was identified as the causative agent of an outbreak of viral pneumonia centered around Wuhan, Hubei, China in Dec 2019, now called as COVID-19. In this article, the current knowledge of deadly, pandemic human coronavirus SARS-Cov2 (COVID-19), with special reference to its zoonosis, susceptibility, and different strategies to develop its therapeutics, will be discussed.
\end{abstract}

Study design: Sources of Corona Virus and Zoonosis, Diagnosis of Corona Virus in Human; Approach for Finding Therapeutics, were highlighted.

Methods: All the information were taken from the several Review and guidelines published by CDC, WHO, NIH, etc.

Results: The zoonosis was shown in Figure 1. Preventive measures, so long any definite cures are available, should be followed as displayed in the Figure 2.

Conclusions: In this review, we summarize the current knowledge on human coronavirus causing COVID-19 infection emphasizing on its impact in human life.

\begin{abstract}
Abbreviations: CoV: Coronavirus; DMV: Double membrane vesicles; FDA: Food and drug administration; hAPN: Human aminopeptidase N; ORF: Open reading frame; SARS: Severe acute respiratory syndrome; IFN: Interferon; MERS: Middle east respiratory syndrome; NHP: Non-human primate; TMPRSSII: Transmembrane protease; HCoV: Human coronavirus; PEDV: Porcine epidemic diarrhea virus; RBD: Receptor binding domain; hACE2: Human angiotensin converting enzyme 2 .
\end{abstract}

\section{Introduction}

The first severe acute respiratory syndrome coronavirus (SARS$\mathrm{CoV}$ ) outbreak in China (in 2003), which spreads out in 29 countries so far and infected about 9000 people with more than $10 \%$ mortality [1]. Soon after five more human coronaviruses (HCoV-229E, HCoV-HKU1, $\mathrm{HCoV}-\mathrm{NL} 63$, and $\mathrm{HCoV}-\mathrm{OC} 43$ ) are found also to be associated with a range of respiratory symptoms, including high-morbidity outcomes such as pneumonia and bronchiolitis [2]. In 2012, another virus MERS$\mathrm{CoV}$ (Middle East Respiratory Syndrome coronavirus), was isolated from a patient with pneumonia in Saudi-Arabia [3]. However, a very recent outbreak of a more severe acute respiratory syndrome (SARS)associated coronavirus (SARS-CoV-2) which one causes COVID-19 disease, a most concerned factor, now-a-days, to human health. Not only the health but it caused a disaster in human social, economic and many other aspects of life, being the disease is highly infectious and fatal too. (Several Review by CDC, WHO, NIH, etc).

In fact, Sars-CoV-2 is originated on $26^{\text {th }}$ December 2019 at Wuhan city of China, and causes a life-threatening pneumonia, and is the most pathogenic human coronavirus identified so far [4]. No statistical data at this point would be perfect since the disease progression as well as mortality rate is increasing at an exponential rate. As of April $4^{\text {th }}, 2020$, according to $\mathrm{CNN}$ reports, the worldwide infected cases are about 1,192,028; Deaths 64,316. In USA, infected cases are 308,533 and death 8,376 .
In this review, we summarize the current knowledge on human coronavirus COVID-19 (since now will be mentioned as such) infection emphasizing on its impact in human life.

\section{Sources of corona virus and zoonosis}

Sars-CoV-2 like other human corona virus, MERS-CoV, SARS$\mathrm{CoV}$, has is originated from Bats [5]. The zoonosis has shown in Table 1.

Like Flu virus, SARS-CoV-2 are capable to infect the respiratory system, and facilitating the spread through coughing and sneezing, especially to the immune-compromised and the elderly people [6], However, unlike to other common cold or allergy issues, SARS-CoV-2 attack mainly lower respiratory tract, and results deadly Pneumonia [7]. No medicine is there yet, either control and/or cure, but only several efforts for prevention.

\section{Diagnosis of corona virus in human}

Chest radiography can reveal a typical feature of bronchiolitis. Identification of unknown pathogens using molecular biology tools is difficult, but genome-specific PCR primers can be designed for RTPCR analysis. The presence of restriction enzyme fragment length polymorphism (RFLP) can also be done.

The Centers for Disease Control and Prevention (CDC) and NIAID has developed a test to diagnose COVID-19 in respiratory and serum samples from clinical specimens $[5,8]$.

${ }^{*}$ Correspondence to: Ashok Chakraborty, Ph.D., Allexcel, Inc. CT, USA, E-mail: ashok.chakraborty@allexcel.com

Key words: SARS, MERS, COVID-19, therapeutics

Received: June 07, 2020; Accepted: June 22, 2020; Published: June 25, 2020 


\begin{tabular}{|l|l|l|}
\hline \multicolumn{1}{|l|}{ Table-1: Comparison of Novel Corona Virus (COVID-19) } \\
with SARS and MERS:
\end{tabular}




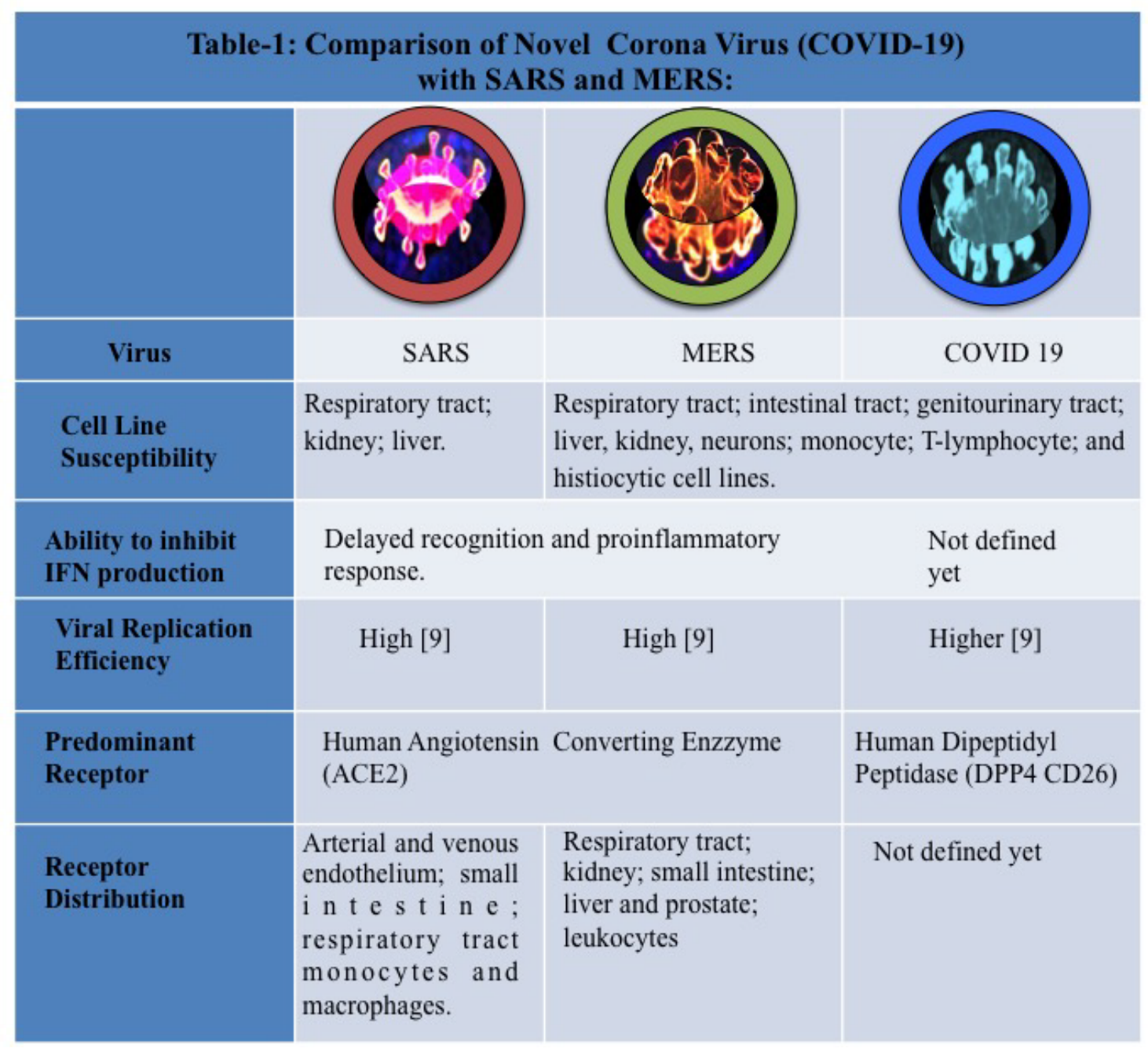

Table 1. Corona virus - basics

\section{COVID-19 (SARS-Cov-2) may be seasonal endemic pathogen}

New Coronavirus COVID-19 that's marked by fevers, coughing, and occasionally severe lung infections, eventually may become a part of the human respiratory-virus repertoire and may not go away without a proper vaccine.

\section{Approach for finding therapeutics}

Coronaviruses are classified into four distinct phylogenetic groups, a-coronaviruses, b-coronaviruses and g-acoronaviruses which infect mammals, and d-coronaviruses infect avian species [9]. Among all known human coronaviruses (HCoV), SARS-CoV-2, like SARS-CoV and MERS-CoV belongs to a $\beta$-corona virus family cause Lower track respiratory problems, whereas others belong to a-type cause only mild upper track infection.

No specific treatment is currently available for human coronaviruses to date, but using the genome knowledge from six previously discovered human coronaviruses, the investigators are examining the progress of the use and development of therapeutic drugs, focusing on the potential roles of virus inhibitors [10].
The innate immune system has a major protective role as the first line of defense against respiratory pathogens. The Receptor determinant identified as $\mathrm{N}$-acetyl-9-O-acetylneuraminic acid or O-Acetylated Sialic acid interferon (IFN) system orchestrates hundreds of different cellular effector proteins that protect the epithelial barrier by altering the physiological and cellular environment, and also impair virus propagation, spread and transmission.

In general, $\mathrm{HCoVs}$ do not elicit a strong innate immune response in primary target cells of the human airway early during infection. Despite the presence of all major pathogen recognition receptors, no elevated expression of IFN beta, pro-inflammatory cytokines or interferon stimulated genes can be observed up to $12 \mathrm{~h}$ post-infection in HAEs infected with HCoV-229E, MERS- or SARS-CoVs [11]. This is most likely due to the intrinsic $\mathrm{CoV}$ properties harbored in the replicative non-structural proteins that actively aid in avoiding recognition by the host innate immune system. For example, the $5^{\prime}$ termini of the viral mRNA are capped making them indistinguishable from the host cellular mRNAs and no longer detectable by cellular sensors.

Vaccines using the spike proteins of both SARS- and MERS-CoVs have proven protective in animal models [12], suggesting that a vaccine against $\mathrm{HCoVs}$ for human use might be achievable. Until any specific 
remedies against COVID-19 becomes available, we must rely on preventive measure that we have displayed in the Table 2.

\section{Conclusions}

Studies with many $\mathrm{HCoVs}$ indicate that $\mathrm{HCoVs}$ including COVID-19 may be more clinically important in the immunecompromised and/or elderly people than previously thought. Since vaccines are not currently available for any of these respiratory viruses, it is necessary to monitor epidemic patterns and investigate the spread of respiratory infections to efficiently identify, control and prevent epidemics.

A detailed study of COVID-19, both genomics and proteomics is needed to know the infection mechanism as well as to drug design. This, however, may be hampered by the lack of an appropriate in vitro as well as in vivo model. Further, future experiments with more sensitive diagnostic tools should yield a more accurate picture of the prevalence of this virus (COVID-19) and its association with respiratory diseases.

\section{COVID-19: Protection and Prevention (Sources: CDC, WHO, NIH, YNHHS)}

\begin{tabular}{|c|c|}
\hline Table-2 & Protection and Prevention \\
\hline \multirow[t]{2}{*}{ Q\#1 } & Can flu and coronavirus infect at the same time? \\
\hline & Possible. \\
\hline \multirow[t]{2}{*}{ Q\#2 } & How about warm weather may stop the COVID-19 infection? \\
\hline & $\begin{array}{l}\text { Some viruses, like the common cold and flu, spread more when the weather } \\
\text { is colder. But it is still possible to become sick with these viruses during } \\
\text { warmer months. At this time, we do not know whether the spread of } \\
\text { COVID-19 will decrease when the weather warms up. }\end{array}$ \\
\hline \multirow[t]{2}{*}{ Q\#3 } & How to prevent COVID-19 infection? \\
\hline & $\begin{array}{l}\text { - Limit contact with people showing symptoms of any respiratory } \\
\text { infection. } \\
\text { - Practice good hygiene to prevent bacteria and viruses from spreading. } \\
\text { - Stay at least } 6 \text { feet away from anyone who is coughing or sneezing. } \\
\text { - Use disinfectants on objects like phones, computers,, etc. }\end{array}$ \\
\hline \multirow[t]{2}{*}{ Q\#4 } & How to increase the strength of immune system? \\
\hline & $\begin{array}{l}\text { Immune system is the body's defense system. These are some to keep our } \\
\text { immune system strong and healthy. } \\
\text { - No smoking. } \\
\text { - Eat a diet high in fruits, vegetables, and whole grains. } \\
\text { - Multivitamin } \\
\text { - Exercise regularly } \\
\text { - Maintain a healthy weight. } \\
\text { - Control stress level; blood pressure; Alcohol drink in moderation } \\
\text { - Get enough sleep. }\end{array}$ \\
\hline
\end{tabular}




\begin{tabular}{|c|c|}
\hline $\begin{array}{l}\text { Table-2 } \\
\text { Contd. }\end{array}$ & COVID-19: Protection/Prevention \\
\hline \multirow[t]{2}{*}{ Q\#5 } & How about going regularly to the work place in this situation? \\
\hline & $\begin{array}{l}\text { - If possible, should stay at home, and work from home. } \\
\text { - If necessary to go into work, maintain } 6 \text { feet of distance from each } \\
\text { other, and wash your frequently with soap and use sanitizer. } \\
\text { - Avoid handshakes, switch in-person meetings to tele-conferences. } \\
\text { and disinfect the workspace with EPA-approved products at the start } \\
\text { of job. }\end{array}$ \\
\hline \multirow[t]{2}{*}{ Q\#6 } & Whether self-isolation is needed if not diagnosed with COVID-19? \\
\hline & $\begin{array}{l}\text { - If returned from an area where an outbreak has been reported, stay } \\
\text { home. } \\
\text { Adults } 60 \text { and older and people with severe chronic illnesses are very } \\
\text { prone to get infected with Covid- } 19 \text {, so the CDC recommends those } \\
\text { people should stay at home, specially where there are outbreaks. }\end{array}$ \\
\hline \multirow[t]{2}{*}{ Q\#7 } & $\begin{array}{l}\text { Why are we so worried about COVID-19, when the flu kills more } \\
\text { people than COVID-19, at least so far? }\end{array}$ \\
\hline & $\begin{array}{l}\text { - Flu has antiviral drugs against, but nothing is available yet for } \\
\text { COVID-19. } \\
\text { - However, the protective and prevention procedure are same for } \\
\text { COVID-19 and Flu, both. }\end{array}$ \\
\hline \multirow[t]{2}{*}{ Q\#8 } & Should a face mask is essential? \\
\hline & $\begin{array}{l}\text { In reality, when you do not know who is the carrier, and also, when } \\
\text { asymptomatic carrier can infect others, it is better to have your own } \\
\text { protection. "I protect you, you protect me" }\end{array}$ \\
\hline
\end{tabular}

Table 2. Covid-19: Protection and prevention (Sources: CDC, WHO, NIH, YNHHS)

\section{Declarations}

Conflict of interests: All the authors declare no competing interests.

Authors' contribution: All the authors contributed equally to prepare this article, read, and approved the final manuscript.

Acknowledgement: We acknowledge all our colleagues for their help during the preparation of the manuscript by providing all the relevant information. Funding from Nanoviricide is highly appreciated.

\section{References}

1. WHO: Cumulative number of reported probable cases of SARS. https://www.who.int/ csr/sars/country/2003_07_11/en/.

2. Woo PC, Lau SK, Tsoi HW, Huang Y, Poon RW, et. al. (2005) Clinical and molecular epidemiological features of coronavirus HKU1-associated community-acquired pneumonia. J Infect Dis 192: 1898-1907.
3. De Wit E, van Doremalen N, Falzarano D, Munster VJ (2016) SARS and MERS: recent insights into emerging coronaviruses. Nat Rev Microbiol 214: 523-534.

4. Cascella M, Rajnik M, Cuomo A, Dulebohn SC, Di Napoli R (2020) Features, evaluation and treatment coronavirus (COVID-19) [Updated 2020 Mar 8]. In: StatPearls [Internet]. Treasure Island (FL): StatPearls Publishing; 2020 Jan. https:/ www.ncbi.nlm.nih.gov/books/NBK554776/

5. NIAID: https://www.niaid.nih.gov/diseases-conditions/covid-19.

6. Pyrc K, Sims AC, Dijkman R, Jebbink M, Long C, et al. (2010) Culturing the unculturable: human coronavirus HKU1 infects, replicates, and produces progeny virions in human ciliated airway epithelial cell cultures. J Virol 84: 11255-11263.

7. Razuri H, Malecki M, Tinoco Y, Ortiz E, Guezala MC et al. (2015) Human coronavirusassociated influenza-like illness in the community setting in Peru. Am J Trop Med Hyg 93: $1038-1040$.

8. CDC: https://www.cdc.gov/coronavirus/2019-ncov/testing-in-us.html. 
9. Lefkowitz EJ, Dempsey DM, Hendrickson RC, Orton RJ, Siddell SG, et al. (2018) Virus taxonomy: the database of the International Committee on Taxonomy of Viruses (ICTV). Nucleic Acids Res 46: D708-D717.

10. Pillaiyar T, Meenakshisundaram S, Manickam M (2020) Recent discovery and development of inhibitors targeting coronaviruses. Drug Discov Today.

11. Kindler E, Jonsdottir HR, Muth D, Hamming OJ, Hartmann R, et al. (2013) Efficient replication of the novel human betacoronavirus EMC on primary human epithelium highlights its zoonotic potential. MBio 4: e00611-e00612.
12. Volz A, Kupke A, Song F, Jany S, Fux R, et al. (2015) Protective efficacy of recombinant modified vaccinia virus Ankara delivering Middle East respiratory syndrome coronavirus spike glycoprotein. J Virol 89: 8651-8656.

13. WHO: COVID-19, March 11, 2020? https://www.who.int/dg/speeches/detail/ who-director-general-s-opening-remarks-at-the-media-briefing-on-covid-19---11march-2020.

Copyright: $@ 2020$ Chakraborty A. This is an open-access article distributed under the terms of the Creative Commons Attribution License, which permits unrestricted use, distribution, and reproduction in any medium, provided the original author and source are credited. 